\title{
Several Problems on Diesel Fuel Oil
}

\author{
by Isao Takahashi \\ (Niigata Iron Works Co.)
}

SYNOPSIS :- The manufacture of high grade gasolines and lubricating oils force the: fuels oils to be lower in grade, and such low grade fuel oils are used for low speed diesel engines to save expenditure in recent trend. The author discusses the effects of low grade fuels for motoring engines from the view point of the nature of oils such as: specific gravity, viscosity, sulfur contents, carbon residue, ash and moisture. On mecha-nical counter-measure for the troubles caused by the low grade fuels, he describes heating of fuel, installation of purifier, use of combustion catalyser and selection of lubricating. oil. He introduced the gas diesel engine using natural gas in Niigata.

\section{閉 会 の 辞}

昭和石油株式会社常務取䋨役 旸 大 雪太 郎

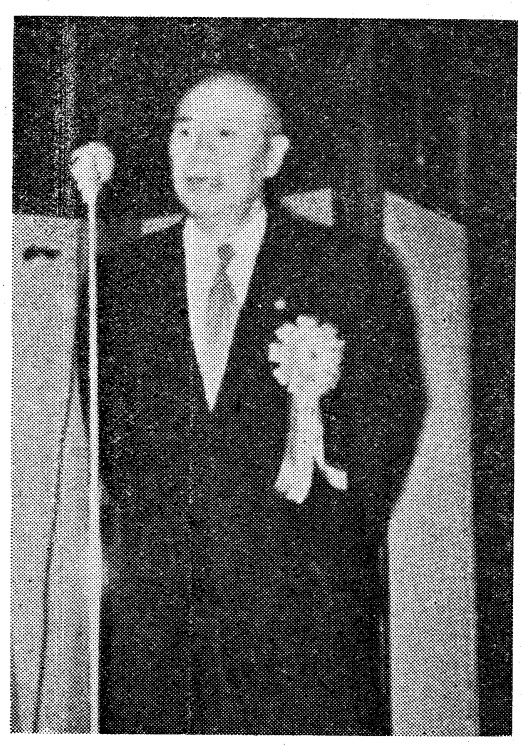

以上をもつて講演者各位の抢話は終りました。時閒の関管 係もありますので簡単に閉会の辞を述へます。今般第22回" 燃料協会大会を当地に開催致すことになりまいたところ， 中央, 地元各地から多数の会員が参集され，また本日は野 坂副知事, 牧山接師, 安東教授扎よび中沢通理氏よりそれ ぞれ新潟県に密接な関倸のある天然がス，石油事業ならび に各種産業について有益な御話をうかがうことのできまし たことは聴蒏各位を稗益するところ大なるものがあり，一 同にかわつて心から御礼申乙上げ，同時に長時間にわたつ。 て熱心に御聴講された各位に深く敬意学表します。な打 元準備委員長として諸事不行届きの点もあつたかと存じま すが，御寛容の程を願つて御挨㩖と致します。 